\title{
Qualitative risk assessment and adaptation strategies for infrastructure on permafrost in the French Alps
}

Pierre-Allain Duvillard (1,2,3), Ludovic Ravanel (1), Philippe Schoeneich (3), Philip Deline (1), Marco Marcer (3) and Florence Magnin (1)

(1) Univ. Grenoble Alpes, Univ. Savoie Mont Blanc, CNRS, EDYTEM, 73000 Chambéry, France.

(2) IMSRN, Parc Pré Millet, Montbonnot, France.

(3) Univ. Grenoble Alpes, Institut d'Urbanisme et de Géographie Alpine - PACTE, Grenoble, France.

Corresponding author: Pierre-Allain Duvillard (pierre-allain.duvillard@univ-smb.fr)

\begin{abstract}
In the current context of climate change, high alpine rock slopes and surficial deposits are affected by geomorphological processes whose evolution is partly conditioned by warming permafrost. This degradation directly implies a rising risk of destabilization for infrastructure in high mountain areas (e.g. huts or ropeway transport systems). In this study, we aim to assess the level of risk of destabilization for infrastructure built on permafrost in the French Alps and to discuss the present adaptation strategies developed by stakeholders. The analysis combines a new inventory of the high mountain infrastructure in the French Alps, with several data layers - including a recently developed map of Potential Thawing Permafrost - analysed within a Geographic Information System. We updated a destabilization risk index previously developed to identify and rank infrastructure at risk with a hazard characterisation and a vulnerability diagnosis (vulnerability s.s. and stakes), based on newly available data. The most at risk infrastructure according to this new risk index is compared with the adaptation strategies of the local stakeholders (managers, scientists) to adapt geotechnical instabilities and/or study the hazard evolution in the present context of climate change. Two adaptations strategies can be distinguished: (1) some cases of proactive strategy focussing on hazard evolution with sometimes preventive geotechnical solutions, climate projections or monitoring of the permafrost initiated by scientists (e.g. monitoring of the thermal state of the permafrost); (2) mainly reactive strategy with different response strategies in the short/medium term by ski-resort managers to repair the infrastructure after a destabilization (e.g. adjustment, adaptation and consolidation, reconstruction or even displacement).
\end{abstract}

Key words: mountain permafrost, infrastructure, adaptation strategies, climate change, French Alps. 


\section{Introduction}

In the current context of climate change, high alpine rock slopes and surficial deposits are affected by geomorphological processes whose evolution is partly conditioned by permafrost degradation/warming (IPCC 2019; Beniston et al 2018). Permafrost is defined as lithospheric materials that remains at or below $0^{\circ} \mathrm{C}$ for at least two consecutive years (van Everdingen 1998). Permafrost covers approximately $20 \times 10^{6} \mathrm{~km}^{2}$ of the planet's emerged land mass, and about a quarter of this is located in mountainous terrain (Gruber 2012). Geomorphological processes affecting rock slopes (e.g. rockfalls, boulder falls) or surficial deposits (e.g. slides, subsidence) are increasing in number and volume due to the evolution of the ice content and its mechanical characteristics (Gruber and Haeberli 2007; Harris et al 2009; Ravanel and Deline 2010; Bodin et al 2017). Changes in precipitation regime (e.g. intense rainfalls in summer; Scherrer et al 2016), combined with rising temperatures, provoke faster mountain permafrost degradation and enables the triggering of geomorphological processes. In frozen surficial deposits increased water content (e.g. formation of taliks, water fluxes in shear horizons) may increase creep rates or even lead to destabilization (e.g. drastic change of kinematic behavior, partial collapse; Marcer et al. 2019; Kenner et al 2017; Luethi et al 2017). Rock slopes can be destabilized by several physical processes including reduction of shear strength, ice segregation and water pressure (Gruber and Haeberli 2007; Krautblatter et al 2013).

In addition to indirect risk for people or infrastructure exposed to process cascades induced by rock or debris failures (e.g. Marcer et al 2019; Mergili et al in discuss) these processes may cause a direct risk of destabilization for infrastructure built in high mountain areas (Schoeneich et al 2011; Haeberli 2013; Arenson and Jakob 2017). In the Alps, these risks may have strong socio-economic implications due to the importance of winter sports (Haeberli 1992; Phillips et al 2007; Ravanel et al 2018), mountaineering activities and structures (Ravanel et al 2013; Mourey et al 2019), communication systems, avalanche defense and protection systems (Phillips 2006), as well as power-generating industries located in permafrost-affected areas. The winter sport industry is widely developed in the French Alps. Several thousands ski lifts have been installed during the last decades, with 947 infrastructure elements built potentially on permafrost in the French Alps (Duvillard et al 2019a). However, special cases like factory destabilization or destruction of mine components found in other mountain ranges are not present in the Alps (e.g. Evans et al 2016).

Because the impacts of climate change may be significant, a next step consists in not only studying the effects on natural systems, but also the possible effects on infrastructure and, in response to anticipated effects, their adaptation (Chappin and Lei 2014). In high mountain environments, recent studies have been carried out on risk and adaptation planning to prevent flash floods (e.g. Allen et al 2018) or glacier lake outburst floods (e.g. Schaub et al 2013; Nussbaumer et al 2014; Haeberli et al 2017). In Arctic permafrost regions, damage characterization studies, proactive adaptation strategies and risk assessment for infrastructure are carried out extensively (e.g. Larsen et al 2008; Melvin et al 2017; Hjort et al 2018), and are often based on expected permafrost evolution using climate change projections (e.g. Shiklomanov et al 2017; Karjalainen et al 2019).

Facing this situation, it is therefore essential to carry out an inventory of infrastructure in permafrost areas and to identify the most exposed sites to support risk adaptation. Risk adaptation strategies about infrastructure instability in high mountain remains a little developed research field. We proposed a first risk index in a previous study (Duvillard et al 2015) to identify and characterize infrastructure potentially at risk. The recently developed maps of permafrost distribution for two 
different geomorphological contexts (i.e. rock wall and surficial deposit; Magnin et al 2015a; Marcer et al 2017; Marcer et al 2019) allows to update and improve this preliminary study.

A recent study presents an historical inventory of damage to infrastructure on permafrost in the French Alps over the past 30 years (Duvillard et al 2019a). After the occurrence of damages on infrastructure, three adaptation strategies were observed: (1) modifying the infrastructure is sometimes sufficient to cope with destabilization (e.g. slight adjustment of the gallows, pendulums or foundations); (2) installing adjustment systems (e.g. floating foundations, laterally adjustable pylons) or consolidating foundations in order to stabilize the structure (e.g. drilling and construction of micro-piles); and, in some cases (3) relocating the infrastructure to a more stable area or rebuilding it after taking into consideration any future movements in order to make it operational again.

The aim of this study is to assess and quantify the risk of destabilization of infrastructure located in permafrost areas in the French Alps and to discuss adaptation strategies presently developed by local stakeholders. There are two main research interests:

(1) an almost exhaustive inventory of the infrastructure located on permafrost allowing an overview of potential high risk infrastructure;

(2) a cross-referenced analysis between the most exposed infrastructure according to the theoretical risk index and the adaptation strategies already used to prevent or to cope with the destabilization.

\section{Study area}

French Alps extend from the Lake of Geneva to the Mediterranean Sea, covering more than $35,000 \mathrm{~km}^{2}$. Permafrost is estimated to cover around $700 \mathrm{~km}^{2}$ (Boeckli et al 2012; Marcer et al 2017) which represents $10 \%$ of the $6,800 \mathrm{~km}^{2}$ located above $2000 \mathrm{~m}$ a.s.l. Since 2005 , the thermal state of a dozen of permafrost-affected sites has been measured in order to study their evolution (PermaFrance network, Bodin et al 2015). Instrumented boreholes, subsurface thermal measurements and monitoring of morphodynamics are used to measure the permafrost state and warming in rock walls $\left(+1.1^{\circ} \mathrm{C} / 10 \mathrm{y}\right.$. at $10 \mathrm{~m}$ deep; Magnin et al 2015b; Ravanel et al 2017b) or in surficial deposits $\left(+0.1^{\circ} \mathrm{C}\right.$ at $10 \mathrm{~m}$ deep ; Bodin et al 2009; Schoeneich et al 2015) in the French Alps, and its response to the ongoing climate change.

The territory is divided between two administrative regions (Auvergne-Rhônes-Alpes and Sud), both of which very dependent on winter and mountain tourism. Two hundred ski resorts represent a total of 3,000 ropeway transport systems (chairlifts, gondola lifts) in addition to other equipments and constructions (power lines, avalanche defenses, huts, etc.) providing 105,000 jobs (Domaines Skiables de France, 2017). There are 947 infrastructure elements with $74 \%$ of them was ropeway transport systems built potentially on permafrost in the French Alps (Duvillard et al 2019a). The French Alps are representative of other Alpine countries (Austria, Germany, Italy, Liechtenstein, Slovenia, Switzerland) with a concentration of high mountain infrastructure. Thus, the European Alps probably represent a unique case in the world by the number of infrastructure on mountain permafrost (Arenson and Jakob 2017).

\section{Inventory of infrastructure on permafrost in the French Alps}

A first inventory of infrastructure located on permafrost (Duvillard et al 2015) was carried out using a Geographical Information System (GIS). This first inventory was compared to the at-that-time available permafrost distribution map, the Alpine Permafrost Index Map (APIM; Boeckli et al 2012). Structures were identified element by element, a pylon being only one "element" of a chairlift while the chairlift (pylons and stations) henceforth is referred as an "infrastructure". The infrastructure elements are: components of ropeway transport systems (lower/top stations and pylons of gondola lifts, chairlifts or 
cable cars), buildings (huts, shelters and chalets), avalanche control and protection systems (gas exploders, snow barriers) as well as communication networks (roads and antennas).

For the present study, we used two recent maps for two different geomorphological contexts (Figure 1A): (1) Permafrost Favourability Index map in the French Alps based on a rock glacier inventory developed for surficial deposits (PFI; Marcer et al 2017) and (2) the Mean Annual Rock Surface Temperature map of the Mont Blanc massif rock walls (MARST; Magnin et al 2015a). This massif concentrates infrastructure on rock walls (e.g. Aiguille du Midi; Magnin et al 2015b. We used two different Digital Elevation Models (DEM) to improve the evaluation of the slope steepness: a $4 \mathrm{~m}$ resolution DEM (RGD 73-74) for the Mont Blanc massif and a 10 m-resolution DEM (IGN) for the other mountain ranges (Vanoise, Écrins).

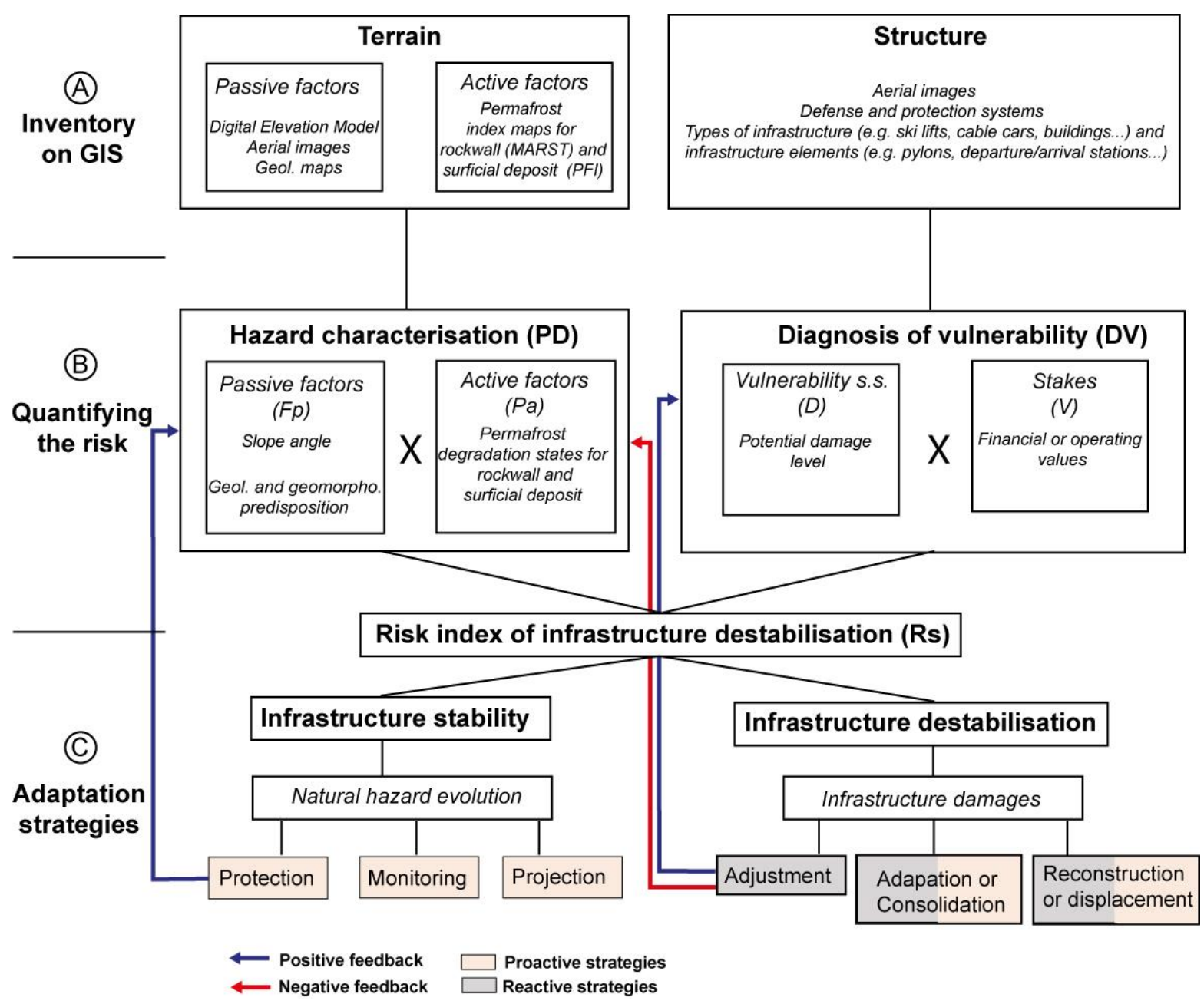

Figure 1: Systemic approach to compare risk index of destabilization and adaptation strategies for infrastructure built on permafrost in the French Alps. (A) Inventory of all the infrastructure. (B) Risk index component combining hazard characterisation and vulnerability diagnosis (Duvillard et al 2015). (C) Adaptation strategies developed by managers and operators.

\section{Methods}

\subsection{Risk index assessment}


The destabilization risk index method proposed by Duvillard et al (2015) to identify and rank infrastructure elements at risk with hazard characterisation and a diagnosis of vulnerabilities (vulnerability s.s. and stakes) was used in this study. This index diverts from traditional geohazard calculations, due to the fact that it is an emergent hazard (the frequency concept cannot be used, since there is almost no experience), and the hazard is the result of an expected and slow evolution of the process under influence of atmospheric warming rather than of identifiable events. Thus, the risk of destabilization is calculated from an evaluation of the sensitivity of the foundation terrain to destabilization, and of the sensitivity of the infrastructure to perturbations. The risk index may be interpreted as the probability that the "destabilizing event" will occur on the infrastructure. The specific risk (value between 0 and 1 ) for every single infrastructure element is defined by the expression (Figure 1B; Figure 2; Bell and Galde 2004; van Westen et al 2005):

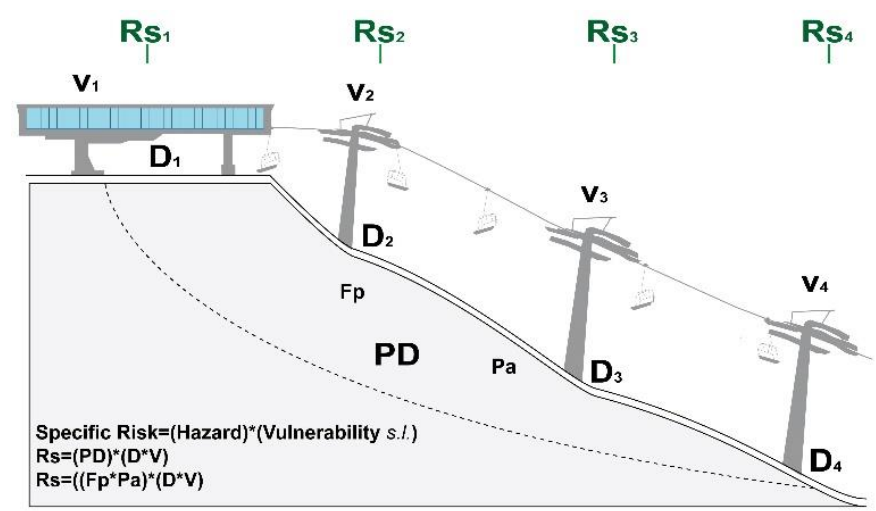

Figure 2: The different components of the risk index for infrastructure built on permafrost in the French Alps.

where Rs: specific Risk; Fp: passive factor (slope angle combined with the geological and geomorphological predisposition); Pa: the potential level of active development (Potential of a Destabilization due to permafrost warming according to the Potential Thawing Permafrost (PTP) distribution (Marcer et al 2019) and the Permafrost Index map of the Mont Blanc massif rock walls (MARST; Magnin et al 2015b); D: the potential level of damage; and V: the index of unitary value for an infrastructure element.

\section{A - Hazard characterization}

To update the risk index, the hazard characterisation was improved for slope angle (passive factor) and permafrost degradation (active factor) assessment.

Slope angle was computed from a more accurate DEM (4 or $10 \mathrm{~m}$ resolution) and/or assessed via the geomorphological context. Four sets of slope angles $(\mathrm{P})$ were chosen in relation with stability limits between debris and rock walls: low $\left(\mathrm{P}<25^{\circ}\right)$, intermediate $\left(25^{\circ}<\mathrm{P}<36^{\circ}\right)$, steep $\left(36^{\circ}<\mathrm{P}<55^{\circ}\right)$ and very steep $\left(\mathrm{P}>55^{\circ}\right)$.

Permafrost degradation was assessed separately for surficial deposits and for rock walls. For surficial deposits, the Potential Thawing Permafrost map (PTP) was first calculated from the difference beteween the PFI map, assumed to reflect the inherited permafrost distribution from LIA and the upward shifted distribution based on present climate. Second the PTP map was combined with an inventory of destabilized rock glaciers in order to assess by a logistic regression the Potential of a Destabilization due to Permafrost degradation (PDP) (Marcer et al 2019). For the rock walls in the Mont Blanc massif, we used the MARST map (Magnin et al 2015; Magnin et al 2017). A value between 0.2 to 0.8 corresponding to the potential of destabilization is associated with each type according to the supposed level of permafrost degradation and MARST (Figure 3). The maximum values were given to areas that correspond to the most unstable temperature ranges according to Ravanel et al (2017). This study has 
shown a concentration of rockfalls in MARST between 0 and $-4^{\circ} \mathrm{C}$ during the 2003 and 2015 summer heatwaves in the Mont Banc massif for the rockwalls.

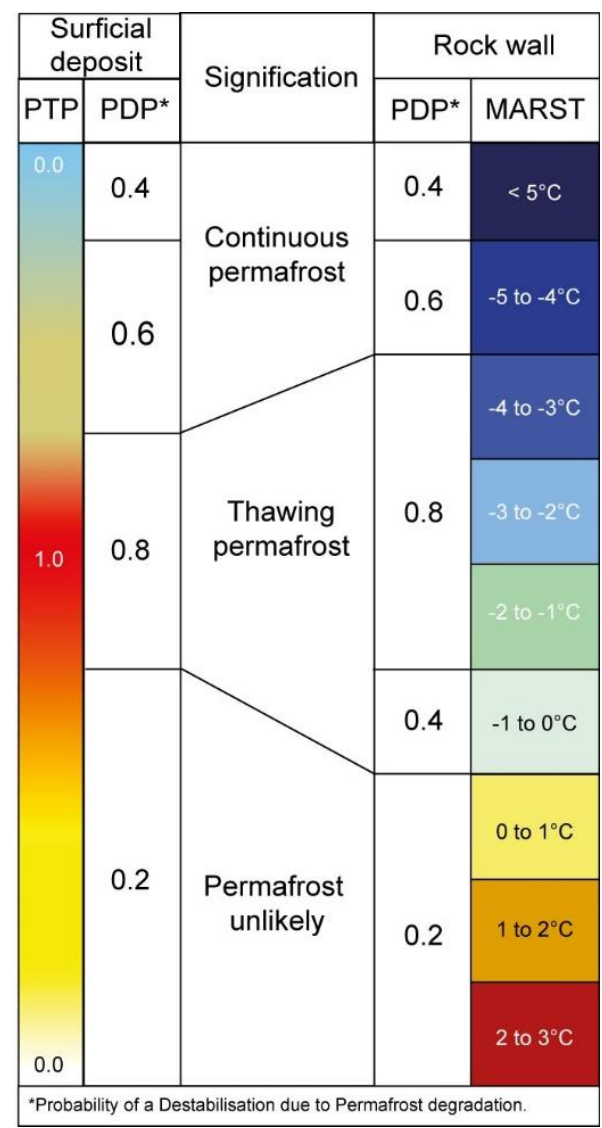

Figure 3: Assessment of destabilization Potential of a Destabilization due to Permafrost degradation (PDP) according the Potential Thawing Permafrost (PTP) distribution (Marcer et al 2019) and the Mean Annual Rock Surface Temperature map of the Mont Blanc massif rock walls (MARST; Magnin et al 2015b).

\section{B - Vulnerability of the infrastructure}

Infrastructure vulnerability can be assessed by considering the potential level of damage (vulnerability s.s.) and the economic/financial value of these elements (stakes):

(1) Infrastructure located in high mountain environment tolerates a level of damage and mechanical failure which varies depending on infrastructure type. Small amplitude movements at the level of the foundations of ski-lift stations or pylons are generally amplified at their top, thereby disturbing the alignment and tension of the cables, which may lead to mechanical or even safety problems. A theoretical classification of the infrastructure based on expert knowledge according to their specific sensitivity and to the consequences of a destabilizing event makes it possible to quantify a theoretical degree of vulnerability. Infrastructure are thus classified on a scale with levels from I to IV (Figure 4; see Arenson et al 2009; Bommer et al 2010).

(2) The vulnerability analysis requires also a hierarchy of the exposed elements (or stakes) in terms of financial (cost of acquisition or building) and operating (economic, strategic, functional) values to determine the infrastructure weight for operators. The index of unitary value $(\mathrm{V})$ of the exposed elements allows a comparison between infrastructure. The knowledge of the financial value of an infrastructure or an estimate of its capacity (e.g. transport capacity, room capacity) enables the operating value of a similar infrastructure to be assessed more precisely. Nevertheless, the construction of this index often contains a subjective evaluation. 


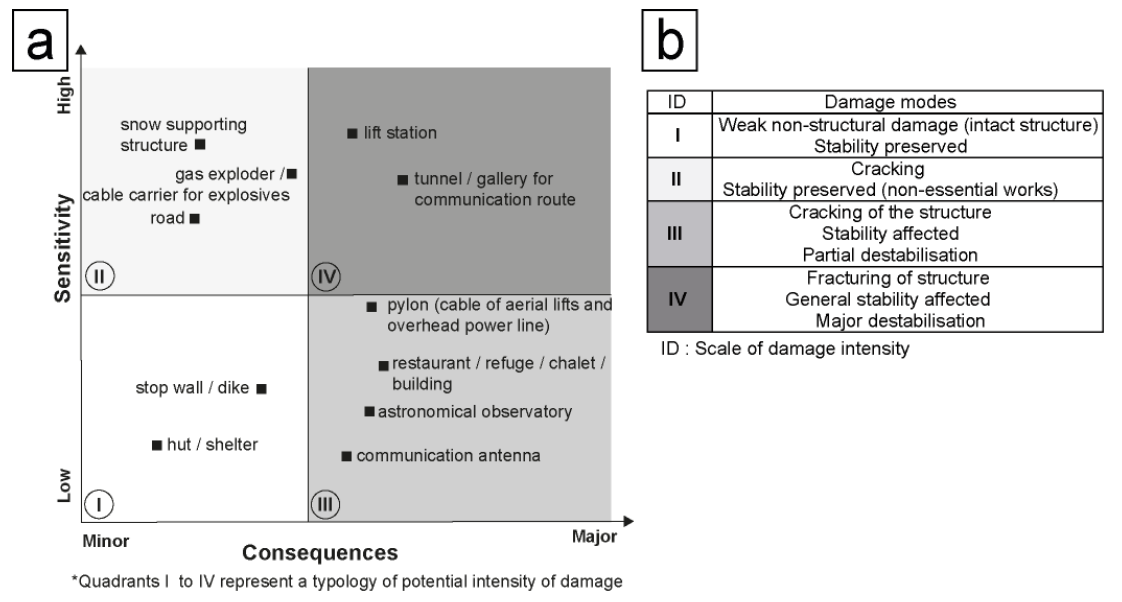

Figure 4: Theoretical vulnerability of the infrastructure. a Relationship between the sensitivity and consequences on the infrastructure in the case of instability (Bommer et al. 2010, modified). b Typology of damage modes and potential damage level for the infrastructure.

\section{C - Specific risk index assessment}

Finally, crossing hazard characterisation and vulnerability s.l. diagnosis allows the construction of a risk index reflecting the degree of risk of destabilisation. Infrastructures were classified according to five degrees of risk, from low to very high (see Duvillard et al 2015).

\subsection{Strategies for infrastructure adaptation}

In a second time, the most at risk infrastructure according to the risk index used (high to very high) were compared with the adaptation strategies of the local stakeholders (managers, engineers and scientists) eventually developed to solve geotechnical instabilities or/and to study the hazard evolution in the current context of climate change. These data were collected by the inventory of infrastructure damages on permafrost in the French Alps (see Duvillard et al 2019a).

Two responses and/or adaptation strategies can be distinguished (Figure 1C; see Füssel 2007): (1) proactive strategy ("response or anticipation capacity") through the implementation of long-term technical solutions or the reconstruction, as well as the monitoring of deformation and/or thermal state, and sometimes climatic projections (e.g. monitoring of the thermal state of the permafrost in Bellecombes and Aiguille du Midi; Bodin et al 2015). (2) a reactive strategy ("coping capacity") through major modifications to infrastructure on short/medium term by resort managers to repair the infrastructure after a destabilization (adjustment, adaptation and consolidation, reconstruction or even displacement).

\section{Results}

\subsection{Inventory of infrastructure on permafrost}

The previous inventory (Duvillard et al 2015) allowed to identify 1655 infrastructure elements located on permafrost according to the APIM map (Boeckli et al 2012). This number drops to 947 infrastructure elements located between 2430 and $4363 \mathrm{~m}$ a.s.l when using the new PFI (Marcer et al 2017) and MARST maps (Magnin et al 2015a). A major part of the elements is located on slopes characterized by a high permafrost probability index, with 352 infrastructure elements on thawing permafrost and 131 on very favourable permafrost condition. 


\subsection{Specific risk index application}

$84 \%$ of infrastructure are indicated on stable underground according to the risk index (4\% low, $35 \%$ limited and $45 \%$ marked). Conversely, $16 \%$ of them are characterised by a high risk of destabilization (147 infrastructure elements), and one infrastructure by a very high risk level (arrival station of the Grands Montets cable car, massif du Mont Blanc). The most at risk infrastructure are mainly ski lifts located in the high-elevated ski resorts, principally in the Vanoise massif (Figure 5).

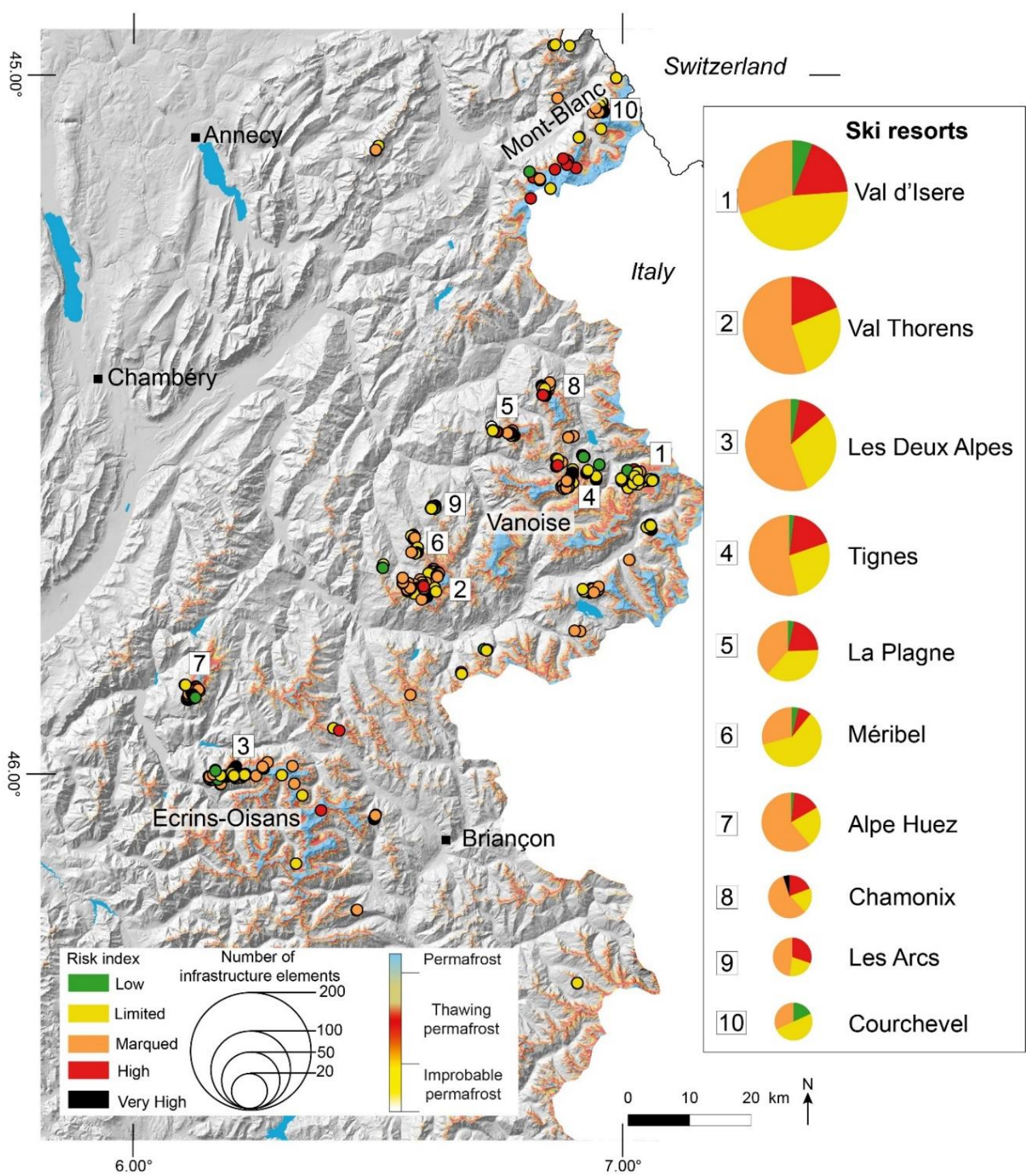

Figure 5: Location of the infrastructure elements at risk in the ski-resorts of the French Alps. The first ten skiresort are detailed. Thawing permafrost map from Marcer et al 2019.

\section{3 Adaptations and response strategies}

Among the 148 most at risk infrastructure elements, 27 infrastructure elements (from 17 infrastructure) have already been concerned by adaptation strategy. It is possible to detect two categories of adaptation and response strategies used either to prevent or to cope a destabilization event (Figure 6): 
(1) a proactive strategy to prevent a destabilization with the monitoring of thermal permafrost state and small movements (e.g. using crack-meters or inclinometers) through scientific programs or by engineering company. The Aiguille du Midi in Chamonix (Mont Blanc massif; one million passengers in 2017) cable-car arrival station is equipped with instrumented borehole, probably partly due to their high value (economic, strategic and operational). One study case with permafrost warming scenarios using climatic projections has been carry on the Aiguille du Midi up the end of the $21^{\text {st }}$ century by scientific programs (Magnin et al 2017). Some infrastructure were built (considering the permafrost) on adjustable structures or with cooling systems (active/passive) in order to save the permafrost (see Arenson et al 2009). These geotechnical considerations significantly increases infrastructure costs, but extents their service life, and the risk of damages is strongly reduced.

(2) A reactive strategy after damages requiring repairs, adjustments of the structure (e.g. laterally adjustable pylons, or drilling and construction of micro-piles) and sometimes reconstruction and displacement. Despite the cost of building and adapting some infrastructure, only 5 infrastructures on the 17 had used geotechnical conception adapt on permafrost (long term solution) to prevent or to cope a destabilization event. For example, the Thorens cable car (Val Thorens) built during summers 2010 and 2011 for $10 \mathrm{M} €$ required additional spending of $700 \mathrm{k} €$ in 2017 in order to consolidate the foundations of one of the pylons, representing $7 \%$ of the original investment only 5 years after its building (Duvillard et al 2019b). In 5 cases, the reconstruction or consolidation solution was adapted in order to prevent new damage due to further degradation of the permafrost.

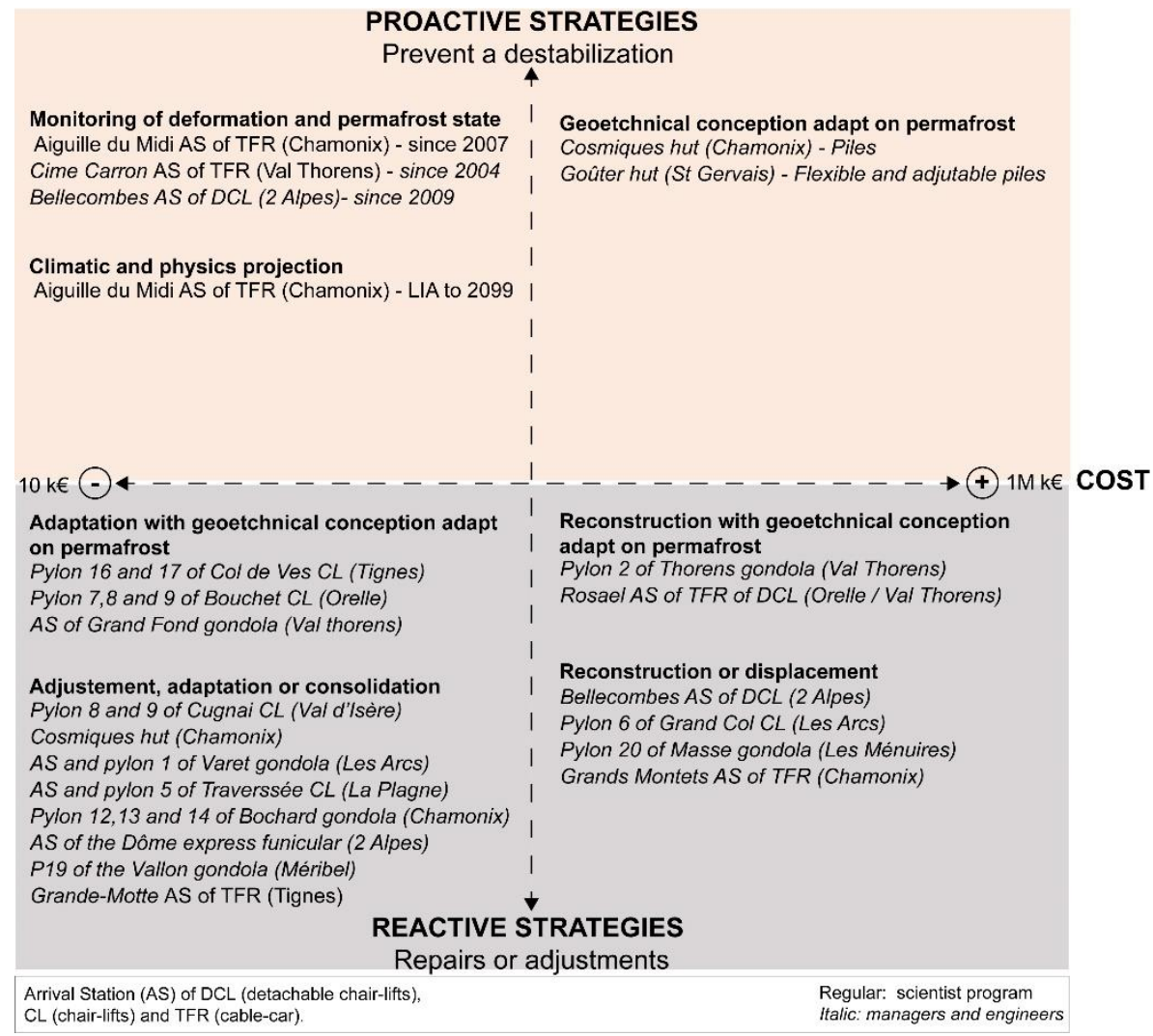

Figure 6: Classification of the strategies developed

\section{Discussion}

\subsection{Risk index methodology}


This risk index has various methodological limitations that future research should solve. (1) The inventory of the ropeway transport systems is not update while there is annually new lifts to modernise or extend the ski resorts. (2) The different permafrost maps indicated the probability of permafrost presence but not the ice-rich content in the underground, often at the origin of the geotechnical disturbance.

This study has general limits due to scale. It is a veritable challenge to assess the stability of local terrain with regional scale data. The data set does not take into account the local disturbance due to the human activities on the water flux or directly due to infrastructure on the permafrost thermal state and distribution.

\subsection{Negative and positive feedbacks}

Theses adaptation strategies set up could induce some negative feedbacks (increasing instability) because of maintenance choices, whereas positive feedbacks (increasing stability and security) could result from the construction type and the monitoring of an infrastructure. These feedbacks could be integrated in the risk index assessment in the future (Figure 1C; Figure 7).

(1) Some of the infrastructure at risk have been built with geotechnical solutions adapting them to the occurrence of mountain permafrost, leading to positive feedback effect. For example, building an infrastructure on stilts as recommended by Bommer et al (2010), adjustable in case of damage and without direct contact with the ground, can reduce the triggering of instability and therefore the vulnerability (s.s.) of the infrastructure. The Goûter hut (Mont Blanc massif; $3835 \mathrm{~m}$ a.s.1.) has been built in 2012 on flexible piles while it is characterised by a high risk of destabilization by the present index (Figure 7a).

(2) Conversely, the rebuilding or maintenance (adaptation or consolidation) could locally accelerate the permafrost degradation due to heat input from the work, and induce a negative feedback on the permafrost. The excavating and drilling of 38 piles during the summer 2017 to stabilize pylon 2 of the Funitel de Thorens probably induced heat flows in the rock glacier and increased the permafrost degradation (Figure 7b; Duvillard et al 2019b).

In order to take into account these positive and negative feedbacks in the risk index calculation, a more in-depth vulnerability (s.s.) assessment and possible assessment of permafrost state would have to be considered.

Because infrastructure that have undergone reconstruction or maintenance works are well documented in Duvillard et al (2019a), the infrastructure risk index could be lowered by 0.2 during the vulnerability diagnosis (i.e. D) due to a lower sensitivity to instabilities. On the contrary, earthworks for stabilization can locally increase the permafrost degradation, and an addition of 0.1 in the PDP assessment could be useful to quantify this negative feedback effect.
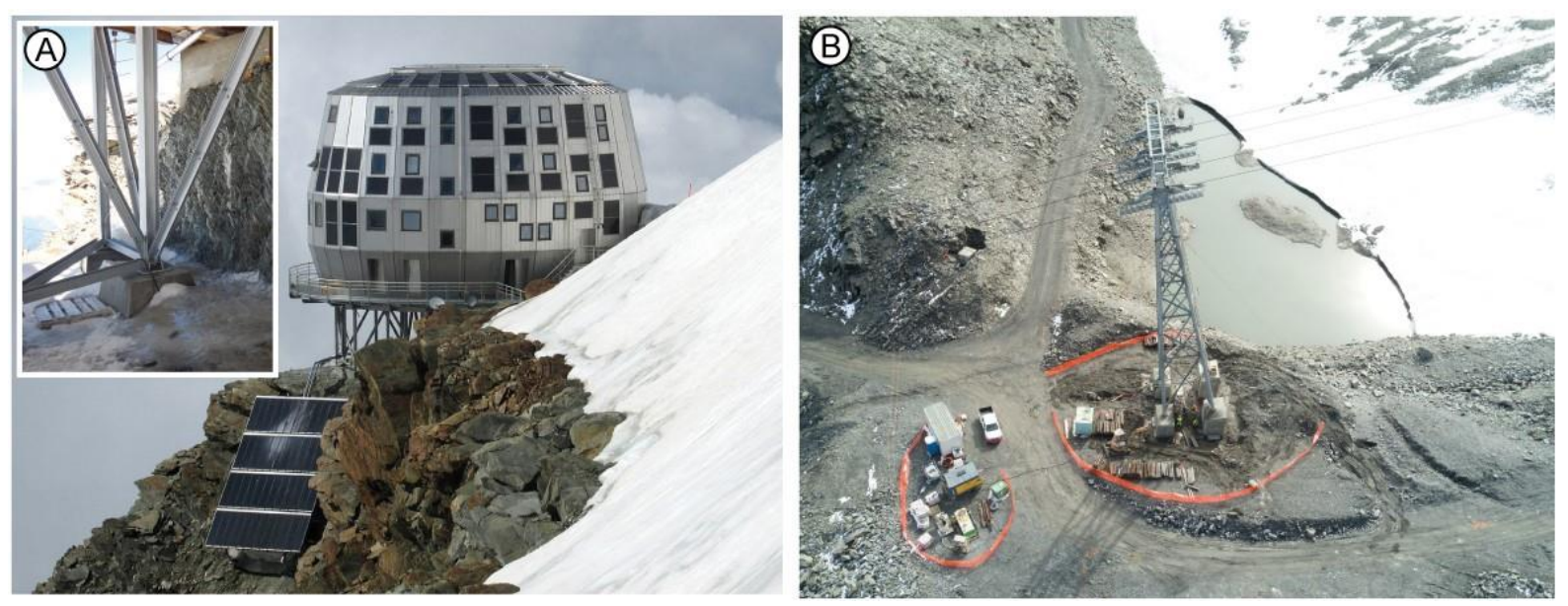
Figure 7: Examples of adaptation strategies developed with possible positive or negative feedback effects on risk index assessment: (A) the Goûter hut (Mont Blanc massif; $3835 \mathrm{~m}$ a.s.1.) built on flexible piles easily adjustable, (B) the drilling works to stabilise the pylon 2 of the Funitel de Thorens (Vanoise massif) with possible negative effects on the local permafrost (enhanced degradation).

\title{
7. Conclusion
}

The risk assessment for infrastructure built or peoples exposed to mountain permafrost hazard are a challenge given the present context of rising temperature. Through a systemic approach, this study attempts to develop a theoretical model of the risk assessment of the destabilization of infrastructure in permafrost-affected high mountain ranges. 947 infrastructure elements were identified in permafrost areas. The application of a destabilization risk index resulted in $84 \%$ of infrastructure beeing characterized of having a low to medium risk, and $16 \%$ having a high risk of destabilization. Among the 148 most at risk infrastructure elements (i.e. high or very high level of risk of destabilization), 27 infrastructure elements (17 infrastructure) have already adopted a reactive adaptation strategy. Only 5 study cases of infrastructures reconstruction or consolidation used long term solution adapted in order to prevent new damage due to further degradation of the permafrost. Conversely, only 5 cases developed proactive strategies to monitor or adapt from the conception the infrastructure on permafrost. However, the strategies set up can induce negative feedback effects because of maintenance choices, whereas inversely it can generate positive feedback effects because of the construction type and the infrastructure monitoring. This feedback will hopefully help to developed a proactive strategies to operate and maintain infrastructure on permafrost in high mountains in the current context of rising temperatures

\section{Author contributions}

P-AD prepared data, made all figures and wrote the initial version of the paper under the supervision and helps of LR and PS. P-AD, LR, PD and PS designed the research project. All the co-authors improved the manuscript.

\section{Acknowledgements}

P.-A. Duvillard's PhD fellowship was supported by a grant from Ingénierie des Mouvements $d u$ Sol et des Risques Naturels (IMSRN) and the Association Nationale de la Recherche et de la Technologie (ANRt). The work is part of the ERDF POIA PermaRisk project and STAAF project.

\section{References}

\begin{abstract}
Allen S.K., Ballesteros-Canovas J., Randhawa S.S., Singha A.K., Huggel C., Stoffel M. 2018. Translating the concept of climate risk into an assessment framework to inform adaptation planning: Insights from a pilot study of flood risk in Himachal Pradesh, Northern India. Environmental Science \& Policy, 87, 1-10. doi:1016/j.envsci.2018.05.013
\end{abstract}

Arenson LU., Phillips M., Springman SM. 2009. Geotechnical considerations and technical solutions for infrastructure in mountain permafrost. In: New Permafrost and Glacier Research. pp 1-47.

Arenson L.U., Jakob M. 2017. Permafrost-Related Geohazards and Infrastructure Construction in Mountainous Environments. Oxf. Res. Encycl. Nat. Hazard Sci., 30. doi:10.1093/acrefore/9780199389407.013.292

Beniston M., Farinotti D., Stoffel M., Andreassen LM., Coppola E., Eckert N., Fantini A., Giacona F., Hauck C., Huss M., Huwald H., Lehning M., López-Moreno JI., Magnusson J., Marty C., Morán-Tejéda E., Morin S., Naaim M., Provenzale A., Rabatel A., Six D., Stötter J., Strasser U., Terzago S. and Vincent C. 2018. The European mountain cryosphere: a review of its current state, trends, and future challenges. The Cryosphere 12:759-794. doi: 10.5194/tc-12-759-2018 
Bell R. and Glade T. 2004. Quantitative risk analysis for landslides - Examples from Bíldudalur, NW-Iceland. Nat Hazards Earth Syst Sci 4, 117-131. doi :10.5194/nhess-4-117-2004

Bodin X., Schoeneich P., Deline P., Ravanel L., Magnin F., Krysiecki JM., Echelard T. 2015. Mountain permafrost and associated geomorphological processes: recent changes in the French Alps. Journal of Alpine Research. doi: 10.4000/rga.2885

Bodin X., Desvarreux P., Fabre D., Krysiecki JM., Gay M., Marie R., Lorier L., Schoeneich P., Vallon M. 2010. Analyse des risques induits par la dégradation du permafrost alpin. Projet Fondation MAIF, Rapport final.

Boeckli L., Brenning A., Gruber S., Noetzli J. 2012. Permafrost distribution in the European Alps: calculation and evaluation of an index map and summary statistics. The Cryosphere. 6:807-820. doi:10.5194/tc-6-807-2012

Bodin X., Krysiecki JM., Schoeneich P., Le Roux O., Lorier L., Echelard T., Peyron M., Walpersdorf A. 2017. The 2006 collapse of the Bérard rock glacier (Southern French Alps). Permafr Periglac Process 28:209223. doi: 10.1002/ppp.1887

Bommer C., Phillips M., Arenson LU. 2010. Practical recommendations for planning, constructing and maintaining infrastructure in mountain permafrost. PermafrPeriglacProcess. 21:97-104. doi: 10.1002/ppp.679

Chappin E.J.L., van der Lei T. 2014. Adaptation of interconnected infrastructures to climate change: A sociotechnical systems perspective. Utilities Policy 31, 10-17. doi:10.1016/j.jup.2014.07.003

Domaines Skiables de France. 2017. Indicateurs et analyse 2017. Observatoire, Rapport annuel.

Duvillard P.A., Ravanel L., Deline P. 2015. Risk assessment of infrastructure destabilisation due to global warming in the high French Alps. Journal of Alpine Research. doi:10.4000/rga.2896.

Duvillard P.A., Ravanel L., Marcer M. and Schoeneich P. 2019a. Recent evolution of damage to infrastructure on permafrost in the French Alps. Reg. Environ. Change. https://doi.org/10.1007/s10113-019-01465-Z

Duvillard P.A., Ravanel L., Schoeneich P., Marcer M., Piard J.F 2019b. Analyse multi-méthodes de la déstabilisation d'un pylône de remontée mécanique implanté sur un glacier rocheux des Alpes françaises. Géomorphologie. Relief. Processus. Environnement. doi:10.4000/geomorphologie.12945

Evans D.J.A., Ewertowski M., Jamieson S.S.R., Orton C. 2016. Surficial geology and geomorphology of the Kumtor Gold Mine, Kyrgyzstan: human impacts on mountain glacier landsystems. Journal of Maps, 12, 757769. doi:10.1080/17445647.2015.1071720

Füssel H.M. 2007. Adaptation planning for climate change: concepts, assessment approaches, and key lessons. Sustainability Science 2, 265-275. doi: 10.1007/s11625-007-0032-y

Gruber S., Haeberli W. 2007. Permafrost in steep bedrock slopes and its temperature-related destabilization following climate change. J Geophys Res 112. doi: 10.1029/2006JF000547

Gruber S. 2012. Derivation and analysis of a high-resolution estimate of global permafrost zonation. The Cryosphere 6:221-233. doi: 10.5194/tc-6-221-2012

Guillet G., Ravanel L., Beutel Y., Deline P. 2018. Fracture kinematics in steep bedrock permafrost, Aiguille du Midi (3842 m a.s.l., Chamonix Mont-Blanc, France). In: Deline P., Bodin X. and Ravanel L. (Eds.) (2018): 5 th European Conference On Permafrost - Book of Abstracts, 23 June - 1 July 2018, Chamonix, France. <hal01816115>

Haeberli W., Noetzli J., Arenson L., Delaloye R., Gärtner-Roer I., Gruber S., Isaksen K., Kneisel C., Krautblatter M., Phillips M. 2010. Mountain permafrost: Development and challenges of a young research field. Journal of Glaciology, 56(200), 1043-1058. doi:10.3189/002214311796406121

Haeberli W. 2013. Mountain permafrost, research frontiers and a special long-term challenge. Cold Reg Sci Technol 96:71-76. https://doi.org/10.1016/j.coldregions.2013.02.004

Haeberli W., Schaub Y., Huggel C. 2017. Increasing risks related to landslides from degrading permafrost into new lakes in de-glaciating mountain ranges. Geomorphology 293:405-417. doi: 10.1016/j.geomorph.2016.02.009

Harris C., Arenson LU., Christiansen HH., Etzelmüller B., Frauenfelder R., Gruber S., Haeberli W., Hauck C., Hölzle M., Humlum O., Isaksen K., Kääb A., Kern-Lütschg MA., Lehning M., Matsuoka N., Murton JB., Nötzli J., Phillips M., Ross N., Seppälä M., Springman SM., VonderMühll D. 2009. Permafrost and climate in Europe: monitoring and modelling thermal, geomorphological and geotechnical responses. Earth-Sci Rev 92:117-171. doi: 10.1016/j.earscirev.2008.12.002

Hjort J., Karjalainen O., Aalto J., Westermann S., Romanovsky V.E., Nelson F.E., Etzelmüller B., Luoto M. 2018. Degrading permafrost puts Arctic infrastructure at risk by mid-century. Nat. Commun. 9. doi: $10.1038 / \mathrm{s} 41467-018-07557-4$ 
IPCC 2019. IPCC Special Report on the Ocean and Cryosphere in a Changing Climate. 1170 p.

Karjalainen O., Aalto J., Luoto M., Westermann S., Romanovsky V.E., Nelson F.E., Etzelmüller B., Hjort J. 2019. Circumpolar permafrost maps and geohazard indices for near-future infrastructure risk assessments. Sci. Data 6. 190037. https://doi.org/10.1038/sdata.2019.37

Kenner R., Phillips M., Beutel J., Hiller M., Limpach P., Pointner E., and Volken M. 2017. Factors controlling velocity variations at short-term, seasonal and multiyear time scales, Ritigraben rock glacier, western Swiss Alps. Permafrost and Periglacial Processes 28: 675-684. doi: 10.1002/ppp.1953

Krautblatter M., Funk D., Günzel FK. 2013. Why permafrost rocks become unstable: a rock-ice-mechanical model in time and space. Earth Surf Process Landf 38:876-887. doi: 10.1002/esp.3374

Larsen PH., Goldsmith S., Smith O., Wilson ML., Strzepek K., Chinowsky P., Saylor B. 2008. Estimating future costs for Alaska public infrastructure at risk from climate change. Global Environmental Change 18:442457. doi: 10.1016/j.gloenvcha.2008.03.005

Luethi R., Phillips M., Lehning M. 2017. Estimating non-conductive heat flow leading to intra-permafrost talik formation at the Ritigraben Rock Glacier (Western Swiss Alps): Estimating non-Conductive Heat Flow. Permafr Periglac Process 28:183-194. doi: 10.1002/ppp.1911

Magnin F, Brenning A, Bodin X, Deline P, Ravanel L. 2015a. Modélisation statistique de la distribution du permafrost de paroi: application au massif du Mont Blanc. Géomorphologie Relief Process Environ. 21:145162. doi:10.4000/geomorphologie.10965.

Magnin F., Deline P., Ravanel L., Noetzli J., Pogliotti P. 2015b. Thermal characteristics of permafrost in the steep alpine rock walls of the Aiguille du Midi (Mont Blanc Massif, 3842 m a.s.l). The Cryosphere 9, 109-121. https://doi.org/10.5194/tc-9-109-2015.

Magnin F., Josnin J.-Y., Ravanel L., Pergaud J., Pohl B., Deline P. 2017. Modelling rock wall permafrost degradation in the Mont Blanc massif from the LIA to the end of the 21st century. The Cryosphere 11, 18131834. https://doi.org/10.5194/tc-11-1813-2017.

Marcer M., Bodin X., Brenning A., Schoeneich P., Charvet R. and Gottardi F. 2017. Permafrost Favorability Index: Spatial Modeling in the French Alps Using a Rock Glacier Inventory. Front. Earth Sci. 5:105. doi: 10.3389/feart.2017.00105

Marcer M., Serrano C., Brenning A., Bodin X., Goetz. J. and Schoeneich P. 2019. Evaluating the destabilization susceptibility of active rock glaciers in the French Alps. The Cryosphere. 13. 141-155. doi:10.5194/tc-13-141-2019

Marcer M., Kummert M., Ringsø Nielsen S., Ribeyre C., Duvillard P.A., Schoeneich P., Bodin X. Génuite K. 2019. Investigating the permafrost slope failures at the Lou rock glacier front. French Alps. Permafr. Periglac. Process.

Mergili M., Jaboyedoff M., Pullarello J., and Pudasaini S.P. In discuss. Back-calculation of the 2017 Piz Cengalo-Bondo landslide cascade with r.avaflow, Nat. Hazards Earth Syst. Sci. Discuss. doi:10.5194/nhess2019-204.

Mourey J., Marcuzzi M., Ravanel L. and Pallandre F. 2019. Effects of climate change on high Alpine environments: the evolution of mountaineering routes in the Mont Blanc massif (Western Alps) over half a century, Arctic, Antarctic, and Alpine Research, doi:10.1080/15230430.2019.1612216.

Melvin AM., Larsen P., Boehlert B., Neumann JE., Chinowsky P., Espinet X., Martinich J., Baumann MS., Rennels L., Bothner A., Nicolsky DJ., Marchenko SS. 2017. Climate change damages to Alaska public infrastructure and the economics of proactive adaptation. Proc Natl Acad Sci 114:E122-E131. doi: 10.1073/pnas.1611056113

Nussbaumer S., Schaub Y., Huggel C., Walz A. 2014. Risk estimation for future glacier lake outburst floods based on local land-use changes. Natural Hazards and Earth System Sciences 14, 1611-1624. https://doi.org/10.5194/nhess-14-1611-2014

Phillips M. 2006. Avalanche defence strategies and monitoring of two sites in mountain permafrost terrain, Pontresina, Eastern Swiss Alps. Nat Hazards, 39:353-379. doi: 10.1007/s11069-005-6126-x

Phillips M., Ladner F., Müller M., Sambeth U., Sorg J., Teysseire P. 2007. Monitoring and reconstruction of a chairlift midway station in creeping permafrost terrain, Grächen, Swiss Alps. Cold Reg Sci Technol, 47:32-42. doi: 10.1016/j.coldregions.2006.08.014

Ravanel L., Deline P. 2010. Climate influence on rockfalls in high-Alpine steep rockwalls: The north side of the Aiguilles de Chamonix (Mont Blanc massif) since the end of the "Little Ice Age." The Holocene 21:357-365. doi: $10.1177 / 0959683610374887$ 
Ravanel L., Deline P., Lambiel C., Vincent C. 2013. Instability of a high alpine rock ridge: the lower arête des cosmiques, mont blanc massif, France. Geografiska Annaler: Series A, Physical Geography 95:51-66. doi: 10.1111/geoa.12000

Ravanel L., Magnin F., Deline P. 2017a. Impacts of the 2003 and 2015 summer heat waves on permafrostaffected rockwalls in the Mont Blanc massif. Science of the Total Environment 609:132-143. doi: 10.1016/j.scitotenv.2017.07.055

Ravanel L., Malet E., Duvillard P-A., Magnin F., Deline P., Guillet G., Troilo F., Pogliotti P., Morra di Cella U., Beutel J. \& Gruber S. 2017b. Instrumentation thermique et cinématique des parois à permafrost du massif du Mont Blanc. Collection Edytem 19 : 27-38.

Ravanel L., Duvillard P-A., Jaboyedoff M., Lambiel C. 2018. Recent evolution of an ice-cored moraine at the Gentianes Pass, Valais Alps, Switzerland. Land Degrad Dev., 1-16. https://doi.org/10.1002/ldr.3088

Schaub Y., Haeberli W., Huggel C., Künzler M., Bründl M. 2013. Landslides and New Lakes in Deglaciating Areas: A Risk Management Framework, in: Margottini, C., Canuti, P., Sassa, K. (Eds.), Landslide Science and Practice: Volume 7: Social and Economic Impact and Policies. Springer Berlin Heidelberg, Berlin, Heidelberg, pp. 31-38. https://doi.org/10.1007/978-3-642-31313-4_5

Scherrer SC., Fischer EM., Posselt R., Liniger MA., Croci-Maspoli M., Knutti R. 2016. Emerging trends in heavy precipitation and hot temperature extremes in Switzerland. Journal of Geophysical Research: Atmospheres, 121:2626-2637. doi: 10.1002/2015jd024634

Schoeneich P., Dall'Amico M., Deline P., Zischg A. 2011. Hazards related to permafrost and to permafrost degradation. PermaNET project, state-of-the-art report 6.2. On-line publication ISBN 978- 2-903095-59-8

Schoeneich P., Bodin X., Echelard T., Kaufmann V., Kellerer-Pirklbauer A., Krysiecki JM., Lieb GK. 2015. Velocity changes of rock glaciers and induced hazards. In: Lollino G, Manconi A, Clague J (eds) Engineering geology for society and territory - volume 1: climate change and engineering geology. Springer international publishing, cham, pp 223-227. doi:10.1007/978-3-319-09300-0_42

Shiklomanov NI., Streletskiy DA., Swales TB., Kokorev VA. 2017. Climate change and stability of urban infrastructure in Russian permafrost regions: prognostic assessment based on GCM climate projections. Geogr Rev 107:125-142. doi: 10.1111/gere.12214

van Everdingen R. (Ed.). 1998. Multi-language glossary of permafrost and related ground-ice terms, Boulder, CO: National Snow and Ice Data Center/World Data Center for Glaciology, (revised May 2005)

van Westen C.J., Van Asch T.W.J., Soeters R., 2005.Landslide hazard and risk zonation-why is it still so difficult?. Bull. Eng. Geol. Environ. 65. 167-184. doi:10.1007/s10064-005-0023-0

Supplementary materials 


\begin{tabular}{|c|c|c|c|c|}
\hline \multicolumn{2}{|r|}{ Elements exposed } & \multirow{2}{*}{$\begin{array}{c}\begin{array}{c}\text { Financial } \\
\text { value } \\
(\mathrm{k} €)\end{array} \\
7500 \\
\end{array}$} & \multirow{2}{*}{$\begin{array}{c}\begin{array}{c}\text { Operating } \\
\text { value }^{2}\end{array} \\
\text { Major }\end{array}$} & \multirow{2}{*}{$\begin{array}{l}\mathrm{V} \\
0.8\end{array}$} \\
\hline \multirow{8}{*}{$\begin{array}{l}\text { Ropeways } \\
\text { transport } \\
\text { system }\end{array}$} & Detachable chairlift & & & \\
\hline & Chairlift & 3000 & Considerable & 0.6 \\
\hline & T bars or rope tow & 500 & Minor & 0.2 \\
\hline & Gondola & 8000 & Major & 0.8 \\
\hline & DMC; Funitel; 3S (big gondola lift) & 13000 & Exceptional & 0.9 \\
\hline & Cable car & - & Exceptional & 0.9 \\
\hline & Funicular & - & Exceptional & 0.9 \\
\hline & Elevator lift & - & Considerable & 0.6 \\
\hline \multirow{6}{*}{ Buildings } & Hut $<30$ people dormitory & - & Considerable & 0.6 \\
\hline & Hut $>30$ people dormitory & - & Major & 0.8 \\
\hline & Hut $>100$ people dormitory & & Exceptional & 0.9 \\
\hline & Restaurant & - & Considerable & 0.6 \\
\hline & Shelter & - & Minor & 0.2 \\
\hline & Chalet / Bui Iding & - & Intermediate & 0.4 \\
\hline \multirow{6}{*}{$\begin{array}{l}\text { Defence } \\
\text { and } \\
\text { protection } \\
\text { systems }\end{array}$} & Gas exploder- Explosive carrier & 80 & Intermediate & 0.4 \\
\hline & Snow avalanche barrier & $0.7 / \mathrm{m}$ & Minor & 0.2 \\
\hline & Wind structure & $0.5 / \mathrm{m}$ & Minor & 0.2 \\
\hline & Gallery / Road tunnel & $30 / \mathrm{m}$ & Considerable & 0.6 \\
\hline & Stop wall / Dike & $0.01 / \mathrm{m}^{3}$ & Minor & 0.2 \\
\hline & $\begin{array}{c}\text { Brakeman structure for snow } \\
\text { avalanche }\end{array}$ & $0.25 / \mathrm{m}^{3}$ & Minor & 0.2 \\
\hline \multirow{2}{*}{ Networks } & Road - Overhead power line pylon & - & Exceptional & 0.9 \\
\hline & Communication antenna & - & Considerable & 0.6 \\
\hline
\end{tabular}

${ }^{1}$ Average duty-free cost for ski lifts in 2012 (Mountain Leaders, Jan/Feb 2013) and equipment and structures against snow avalanche in 2004 2 Economic, strategic, operational

Determination of the index value $(\mathrm{V})$ of different infrastructures 


\begin{tabular}{|c|c|c|c|c|c|c|c|}
\hline & \multicolumn{6}{|c|}{ Hazard $^{1}$} \\
\hline & & 0.01 & 0.04 & 0.16 & 0.36 & 0.64 & 0.81 \\
\hline \multirow{6}{*}{ 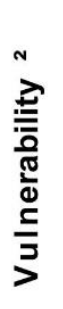 } & 0.01 & 0.0001 & 0.0004 & 0.0016 & 0.0036 & 0.0064 & 0.0081 \\
\hline & 0.04 & 0.0004 & 0.0016 & 0.0064 & 0.0144 & 0.0256 & 0.0324 \\
\hline & 0.16 & 0.0016 & 0.0064 & 0.0256 & 0.0576 & 0.1024 & 0.1296 \\
\hline & 0.36 & 0.0036 & 0.0144 & 0.0576 & 0.1296 & 0.2304 & 0.2916 \\
\hline & 0.64 & 0.0064 & 0.0256 & 0.1024 & 0.2304 & 0.4096 & 0.5184 \\
\hline & 0.81 & 0.0081 & 0.0324 & 0.1296 & 0.2916 & 0.5184 & 0.6561 \\
\hline
\end{tabular}

${ }^{1}$ Result of the probability of occurence of a destabilisation due to permafrost degradation and glacial shrinkage (PD).

${ }^{2}$ Result of the potential damage level (D) multiplied by the index of unitary value (V).

\section{Specific Risk (Rs)}

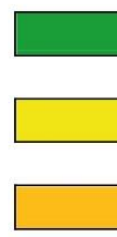

Low

[0.0001-0.0016]

Limited

]0.0016-0.0256]

Marked

]0.0256 - 0.1296]

High

]0.1296-0.4096]

Very high

]0.4096-0.6561]
Definition of risk

Infrastructure stable

Possible weak destabilisation

Possible partial destabilisation

Possible considerable destabilisation

Possible generalized destabilisation

\section{Recommendation}

No analysis needed.

Qualitative analysis recommended 3 .

Realization of qualitative analysis ${ }^{3}$ :

expert opinion, ground reconnaissance and quantitative analysis if no comparable project exists.

Restricted quantitative analysis ${ }^{4}$ : assessment by an engineer, monitoring of the foundations and quantitative analysis if no comparable project exist.

Compulsory monitoring of the structure : detailed quantitative analysis ${ }^{4}$ of the foundations in the field and in the lab., independent expert assessment.

${ }^{3}$ Qualitative analysis : analytic modelling of impacts of ground instability on the structure

${ }^{4}$ Quantitative analysis : detailed numerical modelling.

Risk index of infrastructure destabilisation in high mountains 